Жученко В.Г., к.е. н., дои., Київський національний торговельно-економічний університет, м. Київ, Україна

Google Scholar: https://scholar.google.com.ua/citations?view_op=list_works\&hl

\title{
ТЕНДЕНЦІї РОЗВИТКУ ТУРИЗМУ В УМОВАХ ЕКОЛОГІЗАЦІї МИСЛЕННЯ
}

В умовах глобалізації, інформатизації, технологічності транспортних засобів велика роль відводиться туризму, розвиток якого пов'язаний $з$ уявленням про важливу роль навколишнього середовища в житті людини чи суспільстві, у створенні умов для найбільш повного фізичного, духовного і соціального благополуччя.

Одним із видів туризму, що є важливим способом для передачі молодому поколінню накопиченого людством життєвого досвіду та матеріально-культурної спадщини, формування ціннісних орієнтацій, морального оздоровлення та культурного розвитку нації, одним із шляхів соціалізації особистості є дитячий туризм [1].

Дитячий туризм - це насамперед фізичне вдосконалення, рухова активність, захоплюючий вид відпочинку, а також засіб розширення $\mathrm{i}$ поглиблення знань школярів; чинник зміцнення здоров'я і фізичного розвитку дітей; формування в них патріотизму, почуття дружби й взаємоповаги.

До основних суспільних функцій дитячого туризму можна віднести: рекреаційну, або оздоровчу, результатом якої є підвищення ефективності навчально-виховного процесу дітей; соціокультурну туризм допомагає повноцінно використати вільний час дитини, розширити іiі кругозір, поєднати активний відпочинок з пізнанням світу; виховну - моральне виховання (формування поваги дитини до своїх однолітків, інших людей, довкілля), естетичне (прищеплення дитині любові до культури свого народу та поваги до мистецтва інших народів) i фізичне виховання (орієнтація підростаючого покоління на здоровий спосіб життя, формування активної життєвої позиції) [3].

Одними 3 найпоширеніших організацій дитячого відпочинку $є$ оздоровчі табори. Головною задачею, якого є організація відпочинку дітей. Друга важлива особливість життя в таборі - можливість постійного спілкування 3 природою. Обстановка спільного про- 
живання дітей у групі однолітків дозволяє навчити їх нормам соціального життя, поведінці в колективі, культурі взаємовідносин, розкриттям здібностей дітей, проявом ініціатив, усвідомленню принципу безпечного та здорового образу життя.

Впродовж останніх років в Україні та світі зберігається тенденція до погіршення стану здоров'я населення. Вплив постійно діючих факторів ризику, незадовільна екологічна ситуація, перевантаження, призводять до істотного зниження імунітету та розвитку хронічних захворювань. У світі модно бути здоровим. Цей тренд переходить на туризм. Тому з'явився окремий сегмент туристів, для якого є навіть окрема абревіатура LOHAS (LifestylesOfHealthAnd Sustainability). Вони віддають перевагу зеленому та екологічному туризму, піклуються про навколишнє середовище. Туристи обирають екологічний транспорт, перебування в приватних садибах, харчування продуктами із ферми, навіть якщо вони будуть дорожчими. Вважається, що це преміальний сегмент туризму найближчого майбутнього.

В результаті старіння населення планети у світі стає більше людей третього віку. Деяка частина пенсіонерів має ще кілька, а може i десяток років, доки у них не почнуться проблеми зі здоров'ям. За цей час у них виникає природне бажання побачити світ. Вони не обтяжені сімейними клопотами, дітьми чи кар'єрою. Як правило, такі туристи, готові більше часу провести у цікавих подорожах.[4]

Отже, для підтримання у гарній фізичній формі основної частини трудових ресурсів країни важливу роль потрібно приділяти розвитку дитячого туризму, який сприяє пропаганді здорового образу життя, поліпшенню національно-патріотичного виховання, формуванню гармонічно розвиненої особистості. Дякуючи природним особливостям в Україні можна розвивати всі види відпочинку, які можуть зацікавити молодь.

\section{Список використаних джерел}

1. Дитячо-юнацький туризм в Україні як територіальна соціальноекономічна система, [текст] : автореф дис. на здобуття наукового ступеня д-ра екон. наук спец. 18.10.2005. - туризм / О.В. Колотуха Київ: Київ. ін-т географії. - 22 с.

2. Кляп М.П., Шандор Ф.Ф. Сучасні різновиди туризму : навч. посіб. Київ : знання, 2011. - 334 с.

3. Спеціальні види туризму : підручник / Бабкін А.В 2008. - Харків: ХДУХТ, 2012. - 251c.

4. https://egoistmagaz.in.ua/2017/02/10/ 